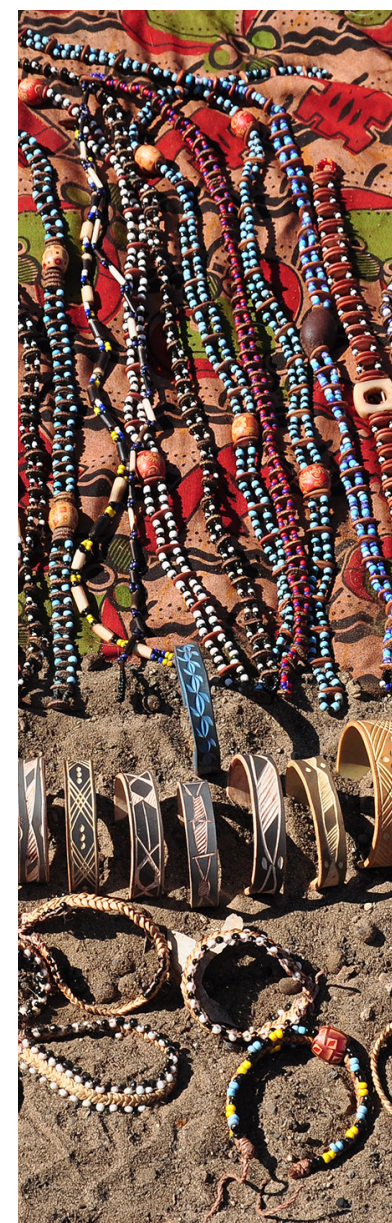

\title{
TOURISM IN PROTECTED AND CONSERVED AREAS AMID THE COVID-19 PANDEMIC
}

\author{
Anna Spenceley ${ }^{1 *}$, Steve $\mathrm{McCool}^{2}$, David Newsome ${ }^{3}$, Ana Báez ${ }^{4}$, James R. \\ Barborak $^{5}$, Clara-Jane Blye ${ }^{6}$, Kelly Bricker ${ }^{7}$, Hery Sigit Cahyadi ${ }^{8}$, Katherine \\ Corrigan $^{9}$, Elizabeth Halpenny 6 , Glen Hvenegaard ${ }^{10}$, Delphine Malleret King ${ }^{11}$, \\ Yu-Fai Leung ${ }^{12}$, Ante Mandić ${ }^{13}$, Robin Naidoo ${ }^{14}$, Dominik Rüede ${ }^{15}$, James \\ Sano ${ }^{16}$, Mahmoud Sarhan ${ }^{17}$, Veronica Santamaria ${ }^{18}$, Thiago Beraldo Sousa ${ }^{19}$ \\ and Anne-Kathrin Zschiegner ${ }^{20}$
}

\author{
Corresponding author: annaspenceley@gmail.com \\ ${ }^{1}$ School of Tourism and Hospitality, University of Johannesburg, South Africa \\ ${ }^{2}$ University of Montana, USA \\ ${ }^{3}$ Environmental and Conservation Sciences Group, Murdoch University, Australia. \\ ${ }^{4}$ Turismo \& Conservación Consultores S.A \\ ${ }^{5}$ Center for Protected Area Management, Colorado State University, Fort Collins, CO, USA \\ ${ }^{6}$ Faculty of Kinesiology, Sport, and Recreation, University of Alberta, Edmonton, $A B$, \\ Canada \\ ${ }^{7}$ Department of Parks, Recreation, and Tourism at the University of Utah, Salt Lake City, \\ Utah, USA \\ ${ }^{8}$ Destination Tourism Studies, Bandung Institute of Tourism, Bandung, West Java, \\ Indonesia.
}

Author affiliations continue on page 117

\begin{abstract}
The COVID-19 pandemic has had a global impact on the tourism sector. With tourism numbers dramatically reduced, millions of jobs could be lost, and progress made in equality and sustainable economic growth could be rolled back. Widespread reports of dramatic changes to protected and conserved ${ }^{1}$ area visitation have negative consequences for conservation finances, tourism businesses and the livelihoods of people who supply labour, goods and services to tourists and tourism businesses. This paper aims to share experiences from around the world on the impacts of the COVID-19 pandemic on protected area tourism; and considers how to build resilience within protected area tourism as a regenerative conservation tool.
\end{abstract}

Key words: sustainable tourism, protected area, conserved areas, parks, COVID-19 pandemic, resilience, impacts, recovery

\section{OVERVIEW OF COVID-19 AND TOURISM}

The COVID-19 pandemic has impacted the tourism sector globally. Between January and May 2020, every global destination imposed travel restrictions, and 45 per cent totally or partially closed their borders to tourists (United Nations World Tourism Organization UNWTO, 2020a). The World Travel and Tourism Council (WTTC) estimates that the COVID-19 pandemic has caused a global loss of up to 174 million direct tourism jobs and the elimination of US\$ 4.7 trillion from the sector's contribution to GDP (a 53 per cent loss compared to 2019) (WTTC, 2020a). With the tourism value chain rolled back, much progress made in sustainable economic growth is at risk (UNWTO, 2020b). This is the scale of uncertainty and change that now threatens tourism.

Before the COVID-19 pandemic, protected areas received roughly 8 billion visits ${ }^{2}$ annually, and generated approximately US $\$ 600$ billion per year in direct in-country expenditures and US $\$ 250$ billion per year in consumer surplus (Balmford et al., 2015). The WTTC (2019) calculated that 21.8 million jobs were supported by wildlife tourism globally, and in Africa over a third of all direct tourism GDP could be attributed to wildlife. Many operators working in protected areas have based their business models on sustainable development principles, and have actively 
contributed to biodiversity conservation and local economic development (Snyman \& Spenceley, 2019; Mitchell \& Ashley, 2010). However, it is difficult to say just how sustainable practices in this sector really are: some destinations suffered from excessive tourism before the pandemic (UNWTO, 2019; Peeters et al., 2018).

For many protected areas, the negative impacts of the COVID-19 pandemic on management capacity, budgets and effectiveness are significant, as are those on the livelihoods of communities living in and around these areas (Hockings et al., 2020). Furthermore, many staff and members of surrounding communities contracted COVID-19, and illness and deaths further reduced agencies' capacity to manage tourism.

This paper aims to: document the diversity of impacts through case studies; describe how protected area tourism is now operating in a COVID-19 pandemic world; and suggest that this opportunity be used to rethink, plan and implement a more holistic tourism. Attaining the UN Sustainable Development Goals is a priority, particularly for vulnerable communities living in or near protected areas (Spenceley \& Rylance, 2019).

\section{CASE STUDIES ON IMPACTS OF THE COVID-19 PANDEMIC ON PROTECTED AREA TOURISM}

The authors have contributed globally-distributed case studies describing the impacts of COVID-19 on protected area tourism. The first section describes the impacts of the pandemic on PCAs, and responses in different countries; the second illustrates the experiences of operators.

\section{Impacts on protected areas}

Brazil: The 334 federally managed protected areas, covering 170 million hectares, reported about 15.3 million visits in 2019. Though all were closed to visitation in March 2020, most reopened between August and October, but with a loss of about 5 million visits over the year (Breves et al., 2020). Re-opened protected areas apply strict health protocols and procedures, including the use of masks, alcohol for sanitising surfaces and social distancing. Based on an economic analysis of tourism's contribution to the Brazilian economy in 2018 (Souza et al., 2020), the reduced number of visitors will lead to a loss of US\$ 1.6 billion in sales for businesses working directly and indirectly with tourism around protected areas. It will also mean that 55,00o permanent or temporary jobs will be lost, employees and businesses will lose US $\$ 410$ million, and Brazil's GDP will be reduced by US $\$ 575$ million.
Namibia: Closure and prohibitions halted tourism in Namibia, which received 1.7 million international travellers in 2019 (Namibia Tourism Board, undated). Initial estimates suggested Namibia's communal conservancies could lose US $\$ 10$ million in direct tourism revenues, threatening funding for 700 game guards and 300 conservancy management employees, and the viability of 61 joint venture tourism lodges employing 1,400 community members (WWF-Namibia, 2020). This will reduce incomes substantially, increasing poverty among households living in conservancies and near protected areas (Naidoo et al., 2015; Naidoo et al., 2019), and forcing families to rely more heavily on natural resource extraction to sustain livelihoods (e.g. hunting wildlife for meat). While the worst of these immediate impacts have been avoided via emergency funds raised to cover critical conservancy shortfalls, poaching of Namibia's iconic Rhinos and Elephants may yet increase. Indeed, the first rhinos poached in a communal conservancy in over two years occurred in April 2020, possibly due to reduced tourism and/or conservation presence. It remains to be seen whether the long-term, cumulative effects of the pandemic lead to the collapse of Namibia's much-lauded communal conservancy programme.

Costa Rica: Nature-based tourism in Costa Rica's national park system is a mainstay of the economy. In 2018, tourism revenue generated 30 per cent of the budget of the National System of Conservation Areas. The COVID-19 pandemic hit Costa Rica during its high season, and visits to protected areas ended abruptly in March 2020. By mid-May, due to business sector pressure, 18 national parks reopened at 50 per cent capacity with strict health protocols. As of June 2020, 27 protected areas had reopened, but visitation was down by nearly 80 per cent because of restrictions on international travel. Despite continued domestic visitation, conservation agency revenues will be reduced since citizens pay only 20 per cent of the national park entry fees that international visitors pay.

Ecuador: During 2019, over 270,000 tourists visited the Galapagos Islands Marine Reserve and National Park. 67 per cent of visitors were international, with tourism contributing 66 per cent of the Galapagos' GDP. Protected areas in the Galapagos were closed to tourism during the second trimester of 2020, but patrolling, exotic species eradication, infrastructure maintenance and monitoring continued, free of tourists for the first time in 60 years. However, economic impacts were dramatic as park operations depend on tourism revenues, as do 3,000 of the Galapagos' 30,000 inhabitants. The shutdown ended on 1 July, but the 


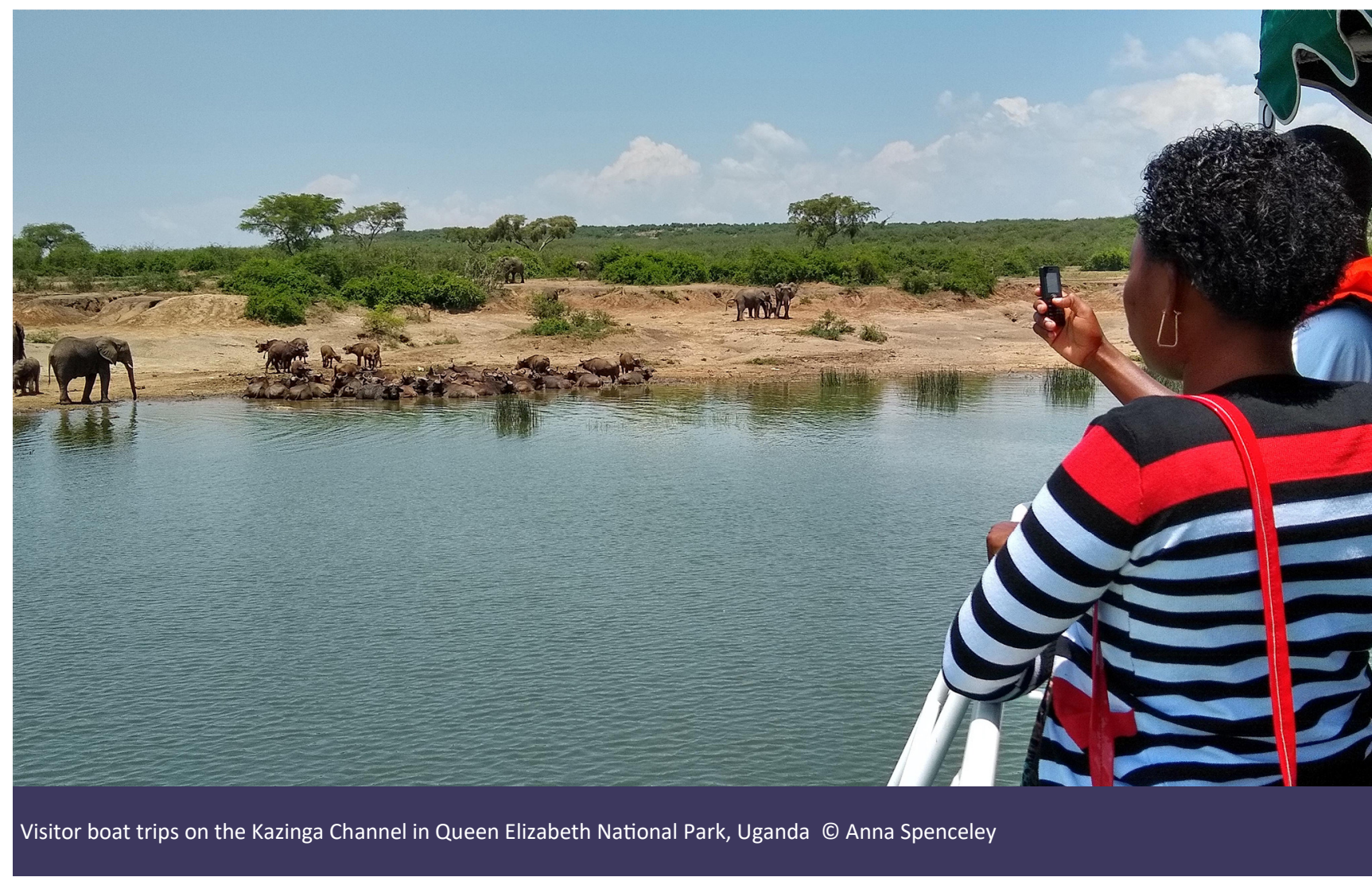

period without visitors gave park managers time to pause, reflect and plan for reopening. Guidelines for tourism reactivation were developed to reduce negative impacts, diversify products and services, and benefit local livelihoods. In future, local operators and guides will offer guided visits to tortoise breeding centres, and six new terrestrial visitor sites will be opened. Many locally based small tour boats will be allowed to operate new routes for day trip activities like snorkelling. Beaches will reopen to visitors and residents, but reservations will be required for sites that had high prepandemic visitation.

Indonesia: In 2019, the Rinjani Geopark in Indonesia received 700,000 visitors who spent 4 billion Rupiah (US\$ 283,00o), while the Lake Toba Geopark had 12.1 million visitors and generated 942 billion Rupiah (US\$ 66.7 million) (Indonesian Geopark Commission, 2019). By April 2020, the government enforced total lockdown, and closed all tourist destinations. The tourism industry and local communities lost jobs (e.g. porters, mountain guides, homestay providers), though national park staff retained theirs. Environmental damage and congestion were reduced. In June, there was a gradual re-opening of natural area tourism sites, albeit with restrictions on visitor use, but congestion has re-emerged despite the COVID-19 pandemic.
Germany: In the Black Forest National Park, visitation increased by 100,000 visits between April and June 2020 compared with the same period in 2019 (a 50 per cent increase). Areas easily accessible from urban areas, and areas within the parks known for their tranquillity reported increased visitation. It is thought that the urban population's desire for nature and the preference for quiet places compared to crowded ones were factors. Many first-time visitors appeared unfamiliar with protected areas or even forests, and more people wanted to camp inside the protected area, which is not allowed. Some visitors justified their non-compliance with park rules as a wish to break free in nature during such restrictive times (Baden-Württemberg.de, 2020; Nationalpark Schwarzwald, 2020)

USA: The pandemic had a considerable impact on US protected areas. For example, in the case of Utah, its five national parks reported that 15.3 million visitors spent an estimated US\$ 1.2 billion in local gateway regions during 2019. This supported 18,900 jobs, generated US\$ 614 million in labour income, and added US\$ 1.1 billion in value and US\$ 1.9 billion in economic output to Utah's economy (National Park Service, 2020a). Economic impacts of COVID-19 closures have been significant. For example, Arches National Park reported about 404,000 fewer visitors between March and May 
2020; by August, though, visitation levels were near average. Communities living around national parks were the hardest hit, with the highest unemployment rates in Utah (DUDSE, 2020; DUDSW, 2020). At the same time, park managers adopted strategies to ensure safer visitation, such as timed entry, signage for social distancing, guidelines for responsible recreation and increased infrastructure cleaning (GNAR, 2020). Other popular national parks in the USA, such as Glacier, Yellowstone and Joshua Tree, reported rapid increases in visitation when they were re-opened.

Canada: Pandemic restrictions impacted provincial park visitors in Alberta, as COVID-19 restrictions changed the way people use parks (Hockings et al., 2020). A 2020 survey of people that had previously visited showed that 85 per cent intended to visit or had already visited a provincial park. Over 80 per cent agreed that parks were safe to visit during the pandemic; 23 per cent felt that provincial parks were safer than other destinations. Of the respondents who did not intend to visit a provincial park, 67 per cent were concerned about becoming infected with COVID19 and 60 per cent did not want to infect others. Only 40 per cent of respondents definitely wanted personal interpretation offered; of interpretive options, respondents preferred amphitheatre programmes (75 per cent) and guided hikes (56 per cent). The main reasons for not attending personal interpretation programmes were concerns about getting infected (37 per cent) and not wanting to infect others (34 per cent). Understanding visitor perceptions of COVID-19 can help parks foster the benefits of interpretation, which include enjoyment, learning and increased parkfriendly attitudes and behaviours (Hvenegaard \& Shultis, 2016; Cook et al., 2019).

\section{Impacts on tourism operators}

Research undertaken for the European Union by Spenceley (2020a) has demonstrated the dramatic effect of the pandemic on protected area tourism economies in Africa. Survey responses from 736 operators working in 41 African countries showed a 63 per cent decline in clients in March 2020 compared to the same time in 2019, with a 72 per cent drop in future bookings. 83 per cent of clients cancelled between March and June 2020, with substantial impacts on local economies. 59 per cent of tourism employees are recruited locally, but because of the crisis 65 per cent are on reduced wages. Operators predict that if the crisis continues, over 17,000 of their local employees would be adversely affected. Local procurement of products, hospitality services and payments to community initiatives are predicted to be US\$ 81 million less than in the previous financial year (a 47 per cent decline). Compounding this is a likely reduction in operator expenditure on local environmental services by US\$ 26 million in 2020. Environmental crime is an immediate concern of 80 per cent of operators and 87 per cent predict that levels will increase because of the pandemic.

The Long Run is an NGO with nature-based tourism business members committed to sustainability3. Member experiences demonstrate how the pandemic is affecting individual operations. For example, in Kenya, 62 per cent of Cottar's Wildlife Conservation Trust's budget usually comes from visitor conservation fees, benefitting 6,000 Maasai families and 7,000 acres of wildlands. At Kicheche Mara Camp, communities mostly rely on tourism revenues earned from employment, land rental, local purchases, handicraft sales and for hiring vehicles. As a result of the pandemic, 74,000 acres of wildlife and ecosystems of the Mara North Conservancy are at risk, making the area vulnerable to poaching, bushmeat hunting and encroachment. A prolonged shut-down could cause irreversible damage because landowners are likely to return to different land uses, and tourism camps would close.

One of the most diverse reefs in the Indian Ocean, Chumbe Island Coral Park in Zanzibar (the first marine protected area in the world), is at risk. Since late March 2020, illegal fishing has been recorded within Chumbe's coral reef sanctuary, threatening nearly 30 years of protection and the nearby fishing grounds of local communities. A similar situation faces the 300,000-acre Misool Private Marine Reserve in Indonesia: without continued support from ranger patrols, the conservation gains made since 2005 could be lost.

A public-private-partnership ecotourism initiative is being implemented in Wadi el Gemal National Park (WGNP) in Egypt (Sarhan, 2016, 2017). The partners jointly operate ecotourism projects providing jobs for the local Ababda tribe, improving their living conditions, supporting tourism businesses, increasing park revenues and boosting the local economy (Sarhan, 2018). Responding to COVID-19, and a dramatic drop in visitation, partners in the WGNP in Egypt are implementing a Crisis Management Plan, financed through the partners' resources and an international donor (Abu Ghosoun NGO, 2020). A package of socioeconomic development programmes is helping to mitigate the social impacts (see Figure 1). These include the Village Savings and Loan Association micro-credit programme, five organic beekeeping projects and a local 
The Context

Wadi el Gemal National Park, Red Sea, Egypt. Unique marine and terrestrial resources, local people, culture heritage, and local and international tourism
The Initiative

In 2016, a public-privatepartnership community-based ecotourism initiative established in Wadi el Gemal National Park
The Partners

The local Ababda tribe, 5-star resort, the National Park, and international donors

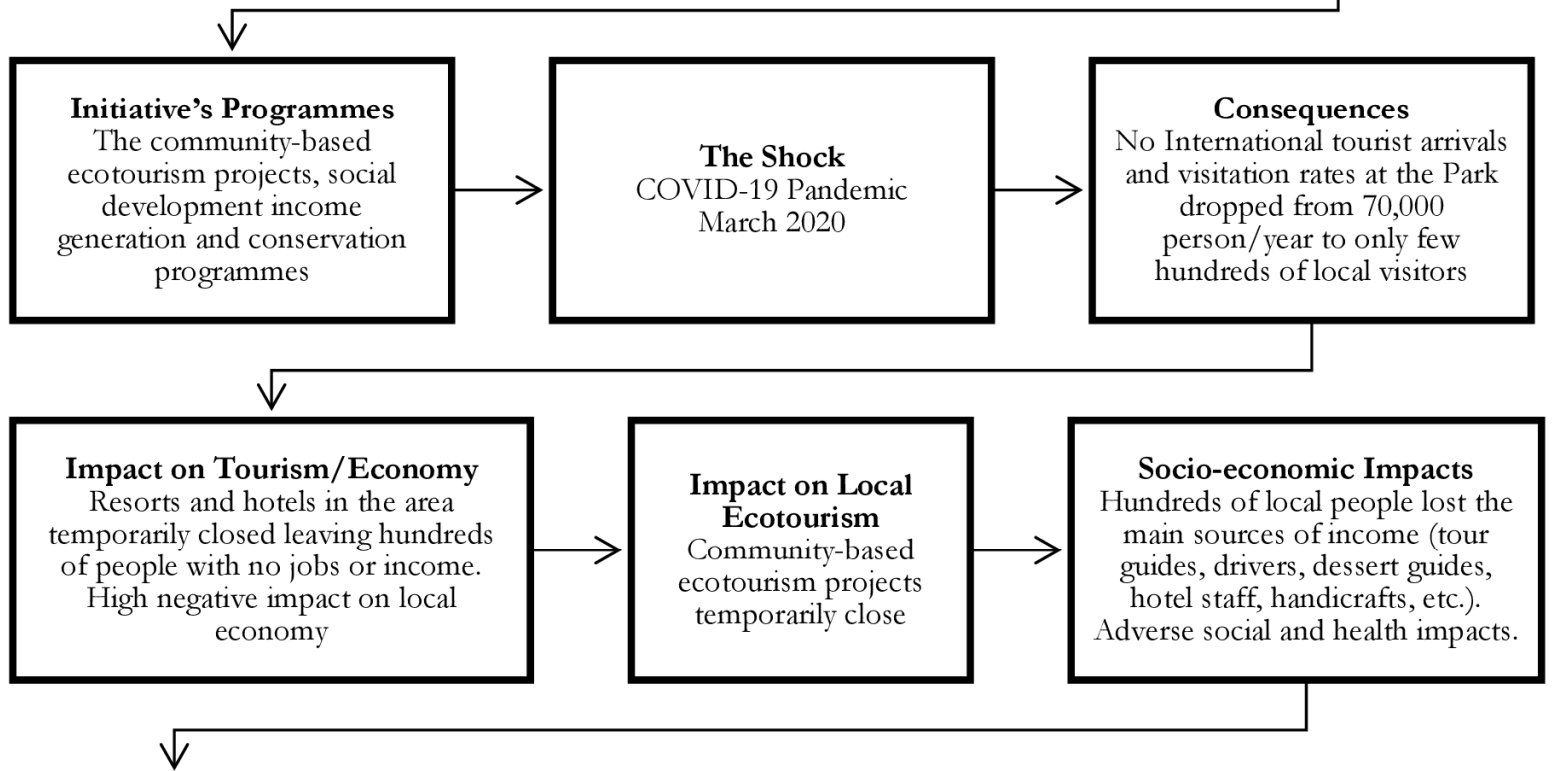

The Response

Consultation process (meetings, discussions, workshops) among the partners of the initiative to respond to the pandemic

\section{Actions}

A COVID-19 Crisis Management Plan developed. Financial and human resources made available. Fundraising from local partners and international donors obtained
Institutional Arrangements Steering Committee with representatives from local people, government, and private sector formed to oversee implementation of Plan

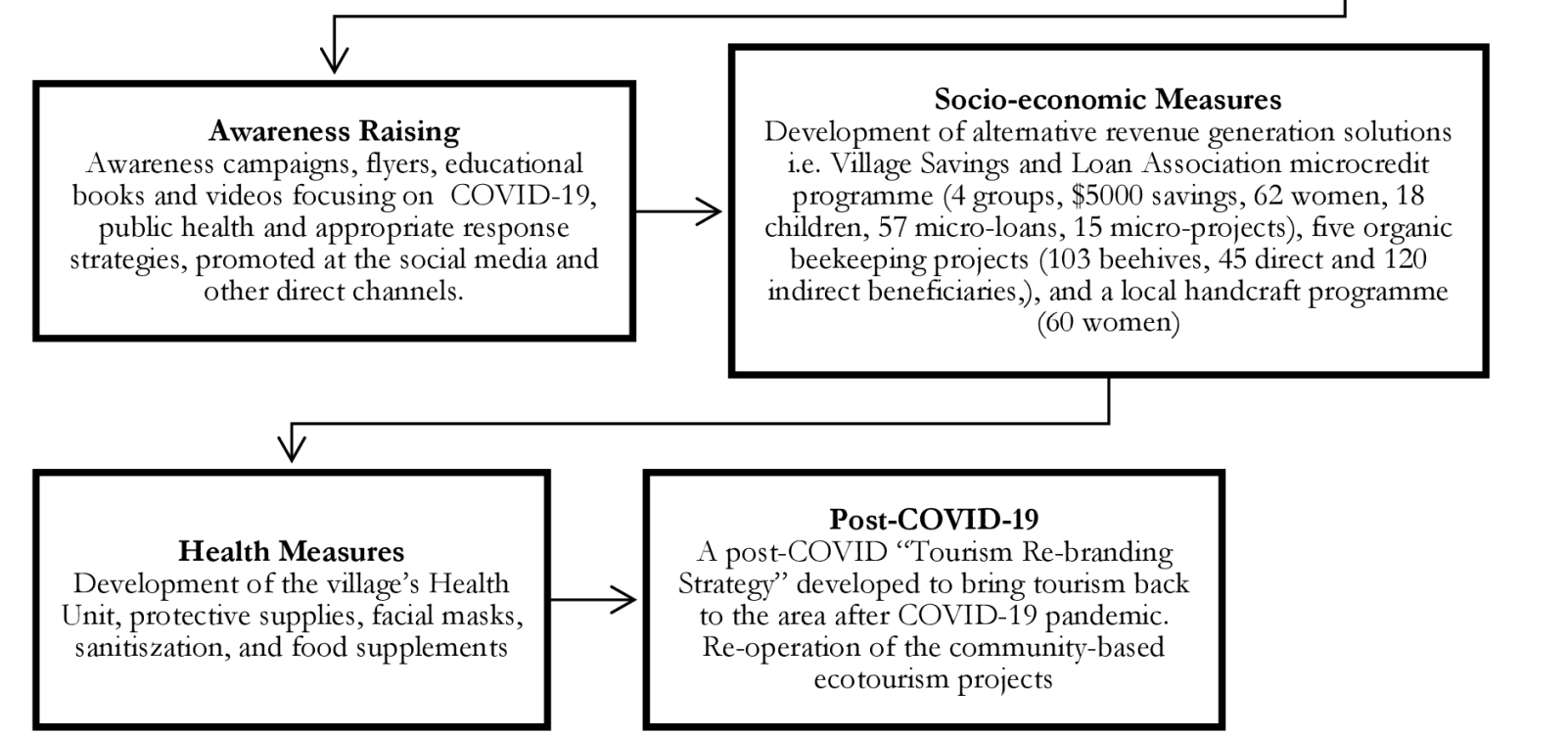

Figure 1. Responding to the Pandemic: The community-based ecotourism public-private partnership initiative in Wadi el Gemal National Park in Egypt 
women's handcraft programme (Elgebal, 2020; Soliman, 2020). Support is also given to the village's Health Unit, as well as supplies of protective equipment, face masks, sanitisation, food supplements, awareness raising materials and training. A post-COVID -19 pandemic 'Tourism Re-branding Strategy' was developed, employing several public relations agencies in Europe to help tourism recover after the pandemic.

The pandemic will probably have immediate and longer -term effects on protected areas. Reduced funds for conservation, and the challenges of reopening parks, may well hinder management efforts and postpone monitoring. Though our present understanding of the full extent of the impacts is limited, it is certain that, in the absence of a revival in international visitor numbers, many protected areas and private sector tourism enterprises will continue to experience devastating revenue and job losses - with consequential damage to conservation and the economy.

Amid the COVID-19 pandemic, there are numerous reports of wildlife and natural areas thriving in the absence of people (see Spenceley, 2020d), suggesting that nature is sending us a message (UN News, 2020). However, there are also challenges where wildlife has become dependent on tourists for food (e.g., Primates and Elephants in Asia: Kretchmer, 2020; Hamdi, 2020). More importantly, conservation and local antipoaching and conservation programmes have had to be cut as tourism revenue collapses (Spenceley, 2020a), resulting in increased levels of poaching in some locations (Hockings et al., 2020).

In response to this, governments, multilateral financial and development institutions and foundations, private equity/venture capital investors and NGOs are coming together to provide emergency liquidity for private sector tourism enterprises and to invest in supporting long-term sustainable recovery programmes that favour biodiversity and poverty alleviation (IUCN, 2020; Spenceley, 2020c, 2020d; Anon, 2020).

\section{MANAGING TOURISM BETTER AND BUILDING RESILIENCY}

This pandemic has highlighted the significant role that protected areas play in human health and wellbeing, "especially after a long period of lockdown or enforced isolation" (Hockings et al., 2020: pp. 16-17). It also demonstrates the interconnectedness between stakeholders and sectors, including private enterprise, public health, government and NGOs. Recovery cannot be achieved by any one sector alone: collaboration is fundamental if we want sustainable tourism and healthy ecosystems, where thriving business are linked to the
KEEP YOUR SOCIAL DISTANCE

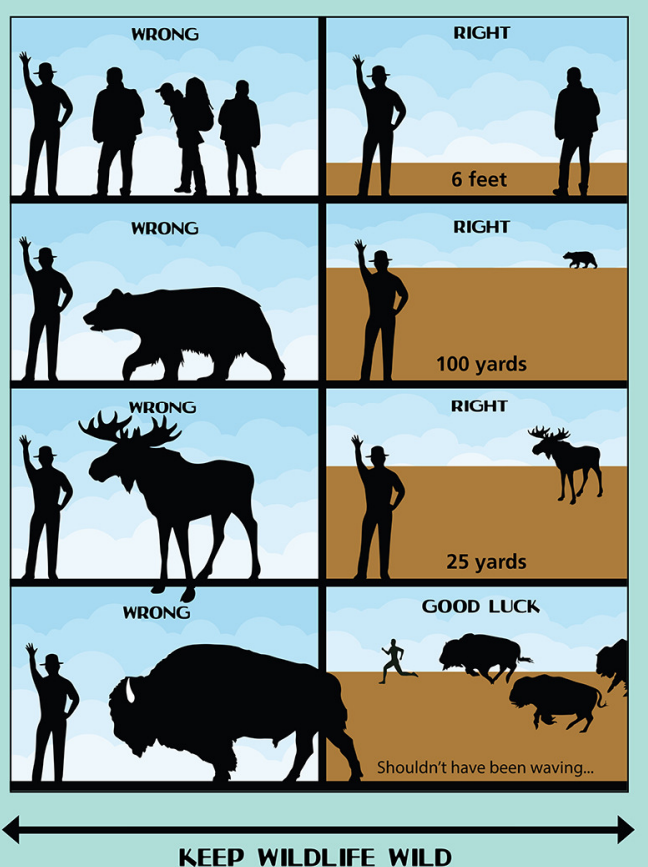

KEEP WILDLIFE WILD

Communicating COVID-19 precautions to tourists in the USA (National Park Service, 2020b)

wellbeing of local people. This section provides examples of constructive responses to the COVID-19 pandemic and strategies for operating visitation amid these conditions.

Managers of protected areas are under pressure to provide facilities for visitors safely (Hockings et al., 2020), but there are challenges because of rapidly changing intelligence and new health and safety requirements. A guidance document developed under a European Union project provides information for protected areas on operating tourism amid the COVID19 pandemic (Spenceley, 2020b). It includes examples and links based on reputable international and national advice, and also protected area authority recommendations. There is information on health and hygiene standards, planning and distribution of visitors, consultation and coordination, managing interactions between wildlife and people (e.g. to avoid further zoonotic disease transmission), and risk assessment analyses (see Kingsford \& Biggs, 2012). The guidance includes suggestions on how to manage visitation safely - with recommendations for before, and when, visitors arrive, including in gateway communities. There is advice on training and equipment for staff, financing interventions and options for online-visits (i.e. where protected areas are not yet able to open). Reviewed by 
representatives of WCPA, UNESCO, WWF and others, this guidance should become a useful resource when reopening natural attractions, even in unique and remote global destinations (e.g. Antarctica: Falk, 2020).

\section{AN OVERVIEW OF TOURISM AND PROTECTED AREAS IN THE TIME OF COVID-19}

Drawing on the case studies and other evidence, we identify several key features of how protected area tourism has been affected by the pandemic (see Table 1 and below).

Visitor numbers fell sharply but have begun to recover: Agencies and the industry have long encouraged public use and outdoor recreation in protected areas, promoting access and inclusivity. While COVID-19 still impacts negatively on tourism, upbeat stories demonstrate the enduring passion for parks that makes outdoor recreation a major economic driver in many countries. After many tourism destinations closed in March 2020, news circulated of the relatively low risk of contagion outdoors and of the safety and health benefits of socially distanced outdoor pursuits in times of social isolation. Many high-density venues remain closed, or with restricted visitation, but COVID-19 has spurred innovation and encouraged dispersed recreation. In many countries, parks that closed have since cautiously reopened. Many governments and the outdoor industry

Table 1. The impact of the pandemic on protected area tourism - summary of experience from the case studies

\begin{tabular}{|c|c|c|c|c|c|c|c|c|}
\hline Effect or Action & $\begin{array}{l}\text { س } \\
\stackrel{\text { N }}{\underline{N}}\end{array}$ & 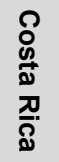 & 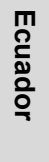 & $\begin{array}{l}z \\
\frac{z}{3} \\
\frac{0}{0}\end{array}$ & $\begin{array}{l}\bar{\Xi} \\
\frac{0}{0} \\
\frac{0}{D} \\
\frac{\infty}{0}\end{array}$ & 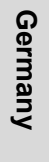 & $\stackrel{\complement}{\infty}$ & 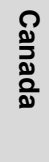 \\
\hline \multicolumn{9}{|l|}{ During lockdown } \\
\hline Reduced number of visitors & $\checkmark$ & $\checkmark$ & $\checkmark$ & $\checkmark$ & $\checkmark$ & & $\checkmark$ & $\checkmark$ \\
\hline Loss of tourism revenue/employment & $\checkmark$ & $\checkmark$ & $\checkmark$ & $\checkmark$ & $\checkmark$ & $\checkmark$ & $\checkmark$ & \\
\hline \multicolumn{9}{|l|}{ Increased number of visitors } \\
\hline \multicolumn{9}{|l|}{ Conservation efforts maintained and scope for site restoration } \\
\hline Reduced management effectiveness/conservation actions & $\checkmark$ & & & $\checkmark$ & & & & \\
\hline \multicolumn{9}{|l|}{ Increased poaching } \\
\hline \multicolumn{9}{|l|}{ Easing of lockdown } \\
\hline Return to pre-lockdown visitation levels & & $\boldsymbol{\nabla}$ & & & $\checkmark$ & $\Delta$ & $\checkmark$ & \\
\hline Change in composition of visitors & & & & & & $\checkmark$ & $\checkmark$ & \\
\hline Non-compliance and anti-social behaviour & & & & & & $\checkmark$ & $\checkmark$ & \\
\hline Renewed concern about visitation and environmental damage & $\checkmark$ & & & & $\checkmark$ & & $\checkmark$ & \\
\hline \multicolumn{9}{|l|}{ Plans for post-COVID-19 recovery } \\
\hline \multicolumn{9}{|l|}{ Review of previous tourism/visitation situations } \\
\hline \multicolumn{9}{|l|}{ Tourism reactivation guidelines } \\
\hline \multicolumn{9}{|l|}{ Innovations } \\
\hline Reservation requirements for high visitation sites & & & $\checkmark$ & & & $\mathbf{X}$ & & $\checkmark$ \\
\hline Timed entry requirements & & & & & & $\mathbf{x}$ & $\checkmark$ & $\checkmark$ \\
\hline New site development & & & $\checkmark$ & & & & & \\
\hline Social distancing rules/education & $\checkmark$ & & & & & $\checkmark$ & $\checkmark$ & $\checkmark$ \\
\hline Cleaning of infrastructure & $\checkmark$ & & & & & & $\checkmark$ & $\checkmark$ \\
\hline
\end{tabular}


have implemented guidelines for staff and visitors to reduce COVID-19 risks, and domestic visitation has rebounded amid the collapse in international visitation. In many US protected areas, campgrounds are full, hiking and biking trails are busy, hunting and fishing license sales are up, and outdoor equipment sales are surging. Some protected areas are visited more now than before the pandemic, despite fear of travel by air and ship. Along with the shift in visitor profiles and decline in visitor spending, protected area visitors can enjoy the associated emotional and health benefits (Hockings et al., 2020; Buckley et al., 2019; Derrien et al., 2019).

Economic recovery is not straightforward: Even where visitor numbers have recovered, protected area revenues and local livelihoods are still suffering. For example, in the USA local and regional park systems that do not collect entrance fees, or charge less for local visitors, cannot recover the increased costs of coping with rising numbers of visitors. Visitors often avoid sitdown restaurants and densely packed tourism venues in gateway communities: so local sales tax revenue is lost and bankruptcies and layoffs may follow.

Safety considerations have been internalised into tourist management: For example, Alberta's provincial parks in Canada maintain their outdoor interpretive programmes but under new rules that require visitors to observe physical distancing (2 metres apart), to wear masks when people interact with others outside their social group, and to use hand sanitisers. They also turn away those who feel unwell or have been exposed to someone who tested positive, limit attendance and space out attendees (e.g. for amphitheatre programmes), and disinfect materials before and after use (Alberta Parks, 2020).

Some parks have developed online ways of sharing nature: Alberta Parks posts engaging webinars on its YouTube channel (Alberta Parks Nature Source, 2020), and 10 per cent of past park users access live webcams or digital tours of Alberta's parks. The Black Forest National Park in Germany put up an online format as a substitute for physical guided tours (Black Forest National Park, 2020).

Innovative ways of supporting tourist-dependent communities are emerging: For example, since the onset of the pandemic, members of The Long Run have held weekly brainstorming events to share lessons on how to help affected local communities. For example, Kualoa Ranch in Hawaii increased agricultural production and established a weekly farmers' market; Nikoi and Cempedak resorts in Indonesia brought back furloughed employees with the help of a community beach clean-up, Seven Clean Seas, to clear waste from beaches on Bintan Island; Caiman Ecological Refuge in Brazil developed tourism reopening protocols with the Brazilian government; Borana in Kenya channelled funds to its Mobile Clinic, visited by more than 700 people each month from vulnerable, remote communities; Kasiiya Papagayo in Costa Rica provided 100 per cent financing for an 'Eco carpentry Shop' to support local entrepreneurship, so creating new revenue streams; and in South Africa, Grootbos Private Nature Reserve's Football Foundation set up a food relief programme to feed more than 2,000 people daily since the pandemic started.

Innovation and product diversification are creating stronger alternative revenue streams in tourism destinations: For example, the $\mathrm{Ku}-\mathrm{Humelala}$ Craft Group in South Africa have pivoted from making craft to sell to tourists to making face masks to protect people from coronavirus (andBeyond, 2020). In Kenya, the Ol Petjeja Conservancy has launched 'The Art of Survival' fund, which can be accessed through an art competition for children; winners get a fully paid trip there once the pandemic is over (Snyman, in DHDNR, 2020). In Alaska, Tutka Bay Lodge on the edge of Kachemak Bay State Park grows most of the produce used in the kitchen in greenhouses and gardens on site. While visitor rooms are empty, the employees are handmaking sausages, pickling and shrimping, learning new skills and developing new offerings (O’Brien, 2020).

The tourist market itself is adapting to the new circumstances: Market research demonstrates that amid COVID-19, people are seeking out adventure travel,

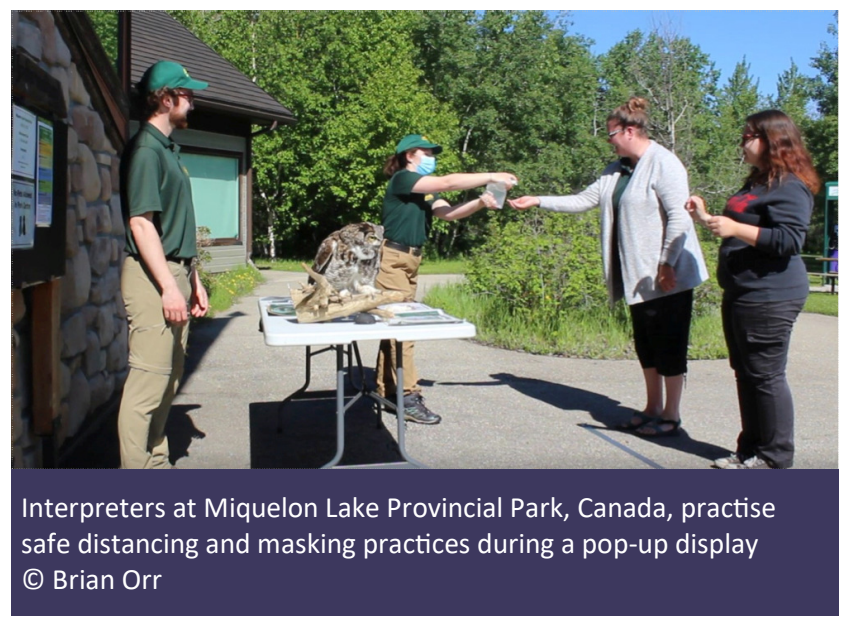


natural spaces and sustainable experiences (WTTC, 2020b; Tripadvisor, 2020; Bremner, 2020a; Galvani et al., 2020; Riley, 2020) (see Figure 2). The market segments of people that visit protected areas are becoming more diverse, with increased numbers of domestic and local travellers (e.g. APAP, 2020; SANParks, 2020). There is growing interest in staycations, micro-adventures and generally in domestic tourism rather than international travel (UNWTO, 2020c; Shoji, 2020; Kinsman, 2020). Domestic tourism can be encouraged through financial incentives, such as preferential pricing packages for local people and holiday vouchers, and through innovative marketing (for example, digital promotion and use of social media channels) (Lindsey et al., 2020; UNWTO, 2020c). However, it may be easier to bridge the financial gap in developed countries, because in many developing countries domestic travellers generate only a fraction of the revenue of internationals (e.g. 20-25 per cent in Kenya: James, 2020; Johnson, 2020): the local market is smaller, often lower entrance fees are charged for local people, and generally locals will spend less on accommodation and activities.

\section{WHAT NEXT FOR PROTECTED AREA TOURISM?}

Before tourism recovery gains momentum, we need first to reflect on how protected areas were performing in the face of massive tourism pressure before the pandemic (e.g. Newsome, 2020). Often such a critical assessment of previous tourism scenarios will reveal opportunities for improvement.

Looking forward, there is much talk of 'building back better'. For tourism, this should not mean a return to business as usual but planning for forms of tourism that address climate change and biodiversity loss (GEF, 2020), and which are more inclusive, equitable and integrated with sustainable development principles. How can we learn from our experience with COVID-19 to ensure a more resilient and sustainable future for this industry? Nobody can predict how the pandemic will evolve, nor the recovery timeline, but stakeholders can identify plausible scenarios and create plans that work across these. Future directions need to build consensus on more sustainable pathways through best practice environmental management and encourage visitors to be more respectful of people, wildlife and the receiving environment. The United Nations World Tourism Organization (UNWTO) has developed a 'One Planet Vision for a responsible recovery of the tourism sector' indicating how a tourism recovery might help achieve a more resilient and sustainable future that works for people and planet (UNWTO, 2020d).

Our experience with COVID-19 shows that resilience is fundamental to the sustainability of protected area

\section{Travel in the new normal: recovery in domestic, intra-regional, then international}
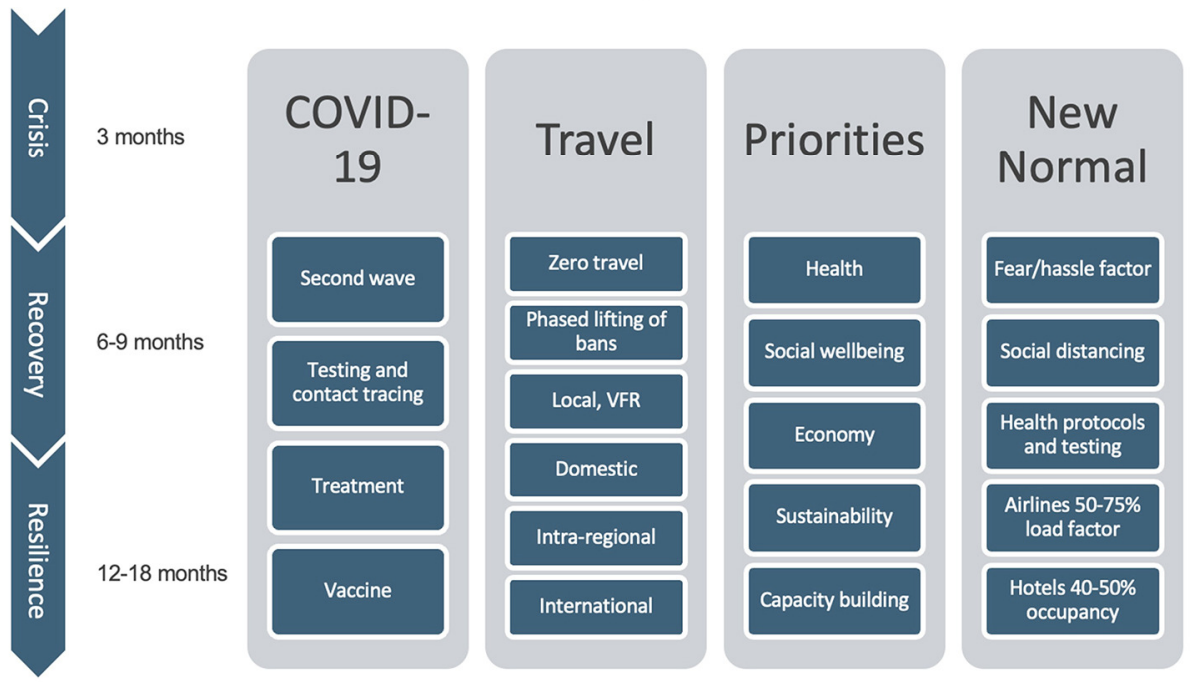

(c) Euromonitor International AN EUROMONITOR

Figure 2. As travel recovers by stages the focus will be more on nature, adventure and sustainability (VFR = visiting friends and relatives) (Bremner, 2020b) 
tourism. 'Resilience' in terms of tourism means: safeguarding the health of visitors, local people and staff; creating more diverse income streams for the local economy; greater attention to equity and inclusiveness; and better understanding of the large-scale context for tourism, globally, such as changes affecting the airline industry (Nunes, 2020). Such challenges must be set in the context of addressing climatic issues and economic disparities.

Rebounding from the effects of the pandemic requires innovative thought about tourism experiences. Examples include: developing alternative land-based economic activities compatible with the destination's needs (e.g. Condor Valley, Argentina); small-scale regenerative agriculture businesses (e.g. Samara Reserve, South Africa); new products and guest experiences that include healthy practices and food; rethinking business models and engaging new markets (e.g. BatuBatu, Malaysia); expanding seasons and tailoring activities to new clients (e.g. Basecamp Oulanka, Finland); and creating virtual experiences such as 'the junior marine biologist programme' (e.g.
SixSenses Laamu, Maldives) and 'Safari Talks' (e.g. African Bush Camps, South Africa). Long-term resilience for protected areas also means strengthening the local economy, securing the financial viability of enterprises and considering the need for long-term investment (e.g. endowment funds) which will help achieve global conservation targets over the long term (Hvenegaard et al., 2012). Through a shift towards digital offerings, protected areas may increase the bonding between conservation and visitors and enable managers to educate people over long distances (Skinner, 2020; Cocks \& Tassiem, 2020).

We recommend that planning for tourism should become more holistic, inclusive, equitable and adaptable and focused on the question of what tourism can sustain. Many of the communities involved are particularly vulnerable to change because of distances from markets and their dependence on natural resources for livelihoods. The way forward for tourism could have five dimensions: (1) fostering openness to change, with a willingness to embrace new ways of thinking and acting; (2) developing a vision for the

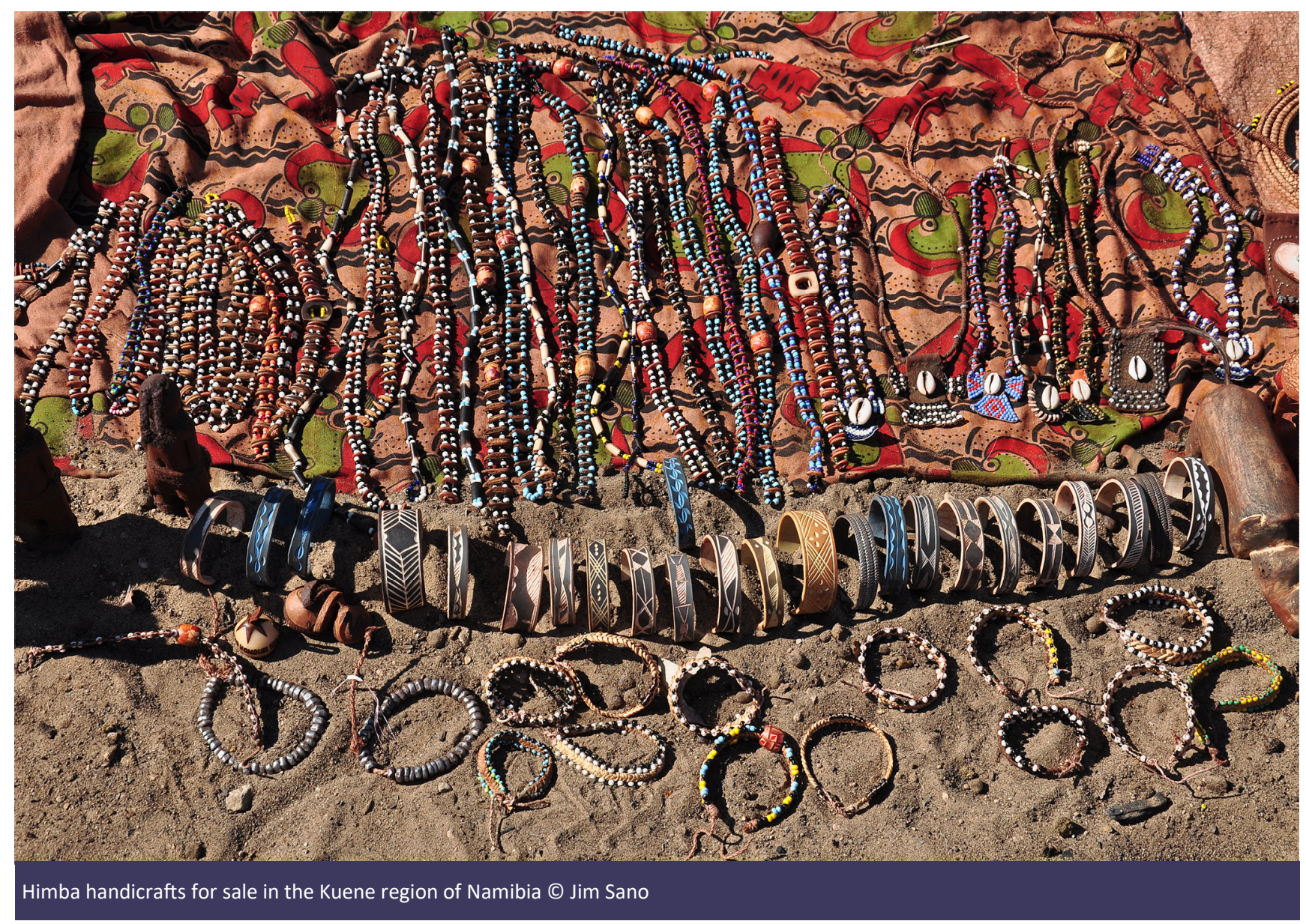


tourism offer of the future; (3) protecting biodiversity for its importance to the ecology of the area and peoples' dependency on tourism; (4) recovering and rebuilding local livelihoods and the health of residents and visitors; and (5) reframing tourism, including the resources it uses, to achieve productive and healthy livelihoods without degrading the biodiversity upon which it depends.

What we have learned from the COVID-19 experience reinforces time-tested principles and practices that have been developed over the years, such as those described in the 'IUCN Best Practice Guidelines' on sustainable tourism (Leung et al., 2018). For example, US federal agencies (National Park Service, US Forest Service, US Fish and Wildlife Service, etc.) have supported the adoption of a Visitor Use Framework which focuses on "managing visitor use to achieve or maintain desired conditions" (IVUM, 2020, p. 1). The experience of the COVID-19 pandemic requires us to see how tourism can promote human health and wellbeing in the destination communities, the health of ecosystems and a deeper visitor experience. The pandemic demonstrated that the most effective and resilient protected areas, particularly those experiencing increasing visitation, had put in place robust management frameworks. Monitoring is essential for professional management, especially during turbulent times when quick decisions must be made, as evidenced by experiences from Brazil and Germany, where monitoring quickly detected changed patterns of visitation, community impacts and ecosystem responses. Several cases suggest the importance of working with local communities and other affected groups to rebuild tourism planning and management. The IUCN Best Practice Guidelines online directory ${ }^{4}$, and major knowledge-sharing platforms, such as Panorama Solutions 5 and the World Bank's Nature-based Tourism Tools and Resources Collection ${ }^{6}$ (World Bank, 2020), capture and share innovative ways in which the crucial role of protected area tourism in conservation and community development may be recovered in the post-pandemic world.

The COVID-19 pandemic has revealed how dependent some conservation areas and many local communities are on tourism, and also the physical and mental health benefits of nature for visitors. But it has also shown how vulnerable tourism is to forces beyond its control. Even if we can overcome the biggest challenges of the coronavirus, tourism may remain vulnerable to uncertainties and risks of subsequent health, security or economic shocks. The only way to make it more robust is to plan for a different type of tourism that is less exploitative, more sustainable and more in tune with the long-term needs of nature, the communities that depend on it, and the tourists themselves. Tourism will remain an economic activity that supports conservation, but more diverse and stable revenues are required to sustain protected area management. Tourism will only thrive if it is adaptable and functions as an essential environmental and social service. This will be possible if it fully integrates the principles of sustainable development, and focuses on equity, inclusiveness and integration better than it has done in the past.

\section{ENDNOTES}

${ }^{1}$ Hereafter referred to as 'protected areas' or as the specific type of protected or conserved area, as defined by IUCN categories and guidance

${ }^{2}$ Throughout the paper we used 'billion' to describe 'thousand million

${ }^{3}$ See http://www.thelongrun.org

${ }^{4}$ https://go.ncsu.edu/iucn-sustainabletourism-bpg

${ }^{5}$ https://panorama.solutions/en

${ }^{6} \mathrm{http}: / /$ appsolutelydigital.com/nbt/filters.html

\section{ABOUT THE AUTHORS}

Anna Spenceley, $\mathrm{PhD}$ is an independent consultant, and Chair of the IUCN WCPA Tourism and Protected Areas Specialist (TAPAS) Group.

Steve McCool is Professor Emeritus at the University of Montana USA and has authored or co-authored many publications on protected area management.

David Newsome is Associate Professor in the Environmental and Conservation Sciences Group, Murdoch University in Western Australia.

Ana L. Báez is a senior consultant and President of Turismo \& Conservación Consultores S.A., a pioneer company in sustainable development issues.

Jim Barborak is Codirector of the Center for Protected Area Management at Colorado State University. He has four decades' experience in nearly 30 countries.

Clara-Jane Blye is currently a PhD candidate at the University of Alberta, in the Faculty of Kinesiology, Sport, and Recreation.

Kelly Bricker is Professor, Chair, Department of Parks, Recreation, and Tourism at the University of Utah. Kelly coordinates the Capacity Building of the TAPAS Group.

Hery Sigit Cahyadi is Associate Professor of Destination Tourism Studies at the Bandung Institute of Tourism in Bandung, West Java, Indonesia. 
Katherine Corrigan is an undergraduate student at the University of Alberta's Augustana Campus in Camrose taking Environmental Studies and Outdoor Education.

Elizabeth Halpenny, $\mathrm{PhD}$, teaches and conducts research in the areas of tourism, marketing, environmental psychology and protected areas management.

Glen Hvenegaard is a Professor of Environmental Science at the University of Alberta's Augustana Campus in Camrose, Alberta.

Delphine Malleret King, PhD heads The Long Run, an organisation which supports a global network of tourism based privately protected areas (PPAs), hosted by NEPCon.

Yu-Fai Leung is Professor, Department of Parks, Recreation and Tourism Management, North Carolina State University. He coordinates the Biodiversity Working Group within the TAPAS Group.

Ante Mandić, $\mathrm{PhD}$ is an Assistant Professor at the University of Split, Faculty of Economics, Business and Tourism, Croatia. Webpage: https://antemandic.com/ ORCiD: https://orcid.org/oooo-0002-2524-6387

Robin Naidoo, $\mathrm{PhD}$ is lead scientist for Wildlife Conservation at World Wildlife Fund (US) and an Adjunct Professor at the University of British Columbia.

Dominik Rüede has been working for Black Forest National Park (Germany) since 2016 on regional development and visitor monitoring.

Jim Sano is World Wildlife Fund's Vice President for Travel, Tourism and Conservation. He was formerly President of Geographic Expeditions at Yosemite National Park.

Mahmoud Sarhan is a conservation and development consultant with experience working with protected areas agencies, government, international nonprofit organizations, and local NGOs.

Verónica Santamaria is Director of the public use area of the Galapagos National Park. Ecuadorian. She has lived for more than 18 years in the Galapagos Islands.

Thiago Beraldo Souza, PhD works for the Chico Mendes Institute for Biodiversity Conservation
(ICMBio) and is Knowledge Development Coordinator of the TAPAS Group.

Anne-Kathrin Zschiegner, $\mathrm{PhD}$ is the Head of Technical Assistance at the LongRun, which supports a global network of tourism based Privately Protected areas.

\section{REFERENCES}

Abu Ghosoun NGO (2020). COVID19 Pandemic Crisis Management Plan Abu Ghosoun Community Development Association, Marsa Alam, Red Sea, Egypt. (Unpublished report). Available at: www.abughosoun.org (Accessed: 15 September 2020).

Alberta Parks Nature Source (2020). Alberta Parks Nature Source, Alberta Parks, Edmonton, AB. Available at: https:// www.youtube.com/channel/UCGQKe-Dy4EZs4GaZxJMA4nA. (Accessed 14 August 2020).

Alberta Parks (2020). Response to COVID-19. Available at: https:// albertaparks.ca/albertaparksca/news-events/response-tocovid-19/. (Accessed: 14 August 2020).

andBeyond (2020). From crafts to masks: South Africa. What do you do when there are no guests to buy your crafts? Turn your talents to a COVID necessity... Available at: https:// www.andbeyond.com/impact/our-impact-platforms/africafoundation/from-crafts-to-masks/? utm_campaign=339779_Indirect_No\%20room $\% 20$ for $\% 201 \%$ 20in\%20COVID-

19_13May2020\&utm_medium=email\&utm_source=Dotdigital \&dm i=5BIT,7A6B,26Z1XH,S701,1 (Accessed: 9 October 2020).

Anon (2020) Investment platform for conservation economies and landscapes in Africa. International Finance Corporation, Space for Giants, Investors in Wildlife, and Dalberg.

Asia Protected Areas Partnership (APAP) (2020). Member update: Korea National Park Service responds to the COVID-19 pandemic, Available at: https:// asiaprotectedareaspartnership.org/index.php/newsarticle? $\mathrm{id}=140$. (Accessed: 15 September 2020).

Baden-Württemberg.de (2020). Corona beschert Nationalpark Schwarzwald Besucherrekorde, 5 August 2020, Available at: https://www.baden-wuerttemberg.de/de/service/presse/ pressemitteilung/pid/corona-beschert-nationalparkschwarzwald-besucherrekorde-2/ (Accessed: 31 August 2020).

Balmford, A., Green, J.M.H., Anderson, M., Beresford, J., Huang, C., Naidoo, R., Walpole, M. and Manica, A. (2015). Walk on the wild side: estimating the global magnitude of visits to protected areas, PLoS Biology 13(2): e1002074.

Black Forest National Park (2020). Neuer Bildungskanal des Wildnisbildungsteams startet. Available at: https:// www.nationalpark-schwarzwald.de/de/nationalpark/blog/2020/ wibidigi/wibidigi-der-nationalpark-zu-hause/ (Accessed: 16 November 2020).

Bremner, C. (2020a). Travel and tourism: Embracing transformation to move beyond Coronavirus. Euromonitor International. Available at: https://hub.wtm.com/travel-andtourism-embracing-transformation-to-move-beyondcoronavirus/ (Accessed: 6 October 2020). 
Bremner, C. (2020b). Travel 2040: Sustainability and digital transformation as recovery drivers. Euromonitor International. Available at: https://go.euromonitor.com/wb-video-travel-2020 -travel-2040.html (Accessed: 5 October 2020).

Breves, G.S.S., Barbosa, E.F.P., Garda, A.B. and Souza, T.V.S.B (2020). Monitoramento da Visitação em Unidades de Conservação Federais: Resultados de 2019 e Breve Panorama Histórico. Brasilia, Brasil: ICMBio.

Buckley, R., Brough, P., Hague, L., Chauvenet, A., Fleming, C., Roche, E., Sofija, E. and Harris, N. (2019). Economic value of protected areas via visitor mental health. Nature Communications 10: 5005.

Cocks, T. and Tassiem, S. (2020). South Africa 'virtual safaris' liven up lockdown with jackals and leopard cubs. Reuters. 6 May 2020. Available at: https://www.reuters.com/article/ushealth-coronavirus-safrica-virtual-sa-idUSKBN22I14B. (Accessed: 26 November 2020).

Cook, K., Hvenegaard, G.T. and Halpenny, E.A. (2019). Visitor perceptions of the outcomes of personal interpretation in Alberta's provincial parks. Applied Environmental Education \& Communication. DOI:10.1080/1533015X.2019.1693309.

Department of Human Dimensions of Natural Resources (DHDNR) (2020). Protected areas for all. Webinar series part 1: Session 1A Protected area tourism beyond 2020. (Webinar). 26 August 2020. Available at: https:// www.youtube.com/watch? feature=youtu.be\& $v=\mid O K S 8 M 35 c N E \& a p p=$ desktop (Accessed: 1 October 2020).

Derrien, M., Cerveny, L. and Wolf, K. (2019). The human health dimensions of sustainable tourism. In: S.F. McCool and K. Bosack (eds.) A Research Agenda for Sustainable Tourism, pp. 150-158. Cheltenham, UK: Edward Elgar Publishing.

Division of the Utah Department of Workforce Services (DUDSSE): Research and Analysis Division (2020). Southeast's Labor Market and Economy. Available at: http:// utaheconomysoutheast.blogspot.com/2020/06/unemployment -insurance-claims-data-shed.html (Accessed: 24 August 2020).

Division of the Utah Department of Workforce Services (DUDSSW): Research and Analysis Division (2020). Southwest's Labor Market and Economy. Available at: http:// utaheconomysouthwest.blogspot.com/2020/05/

unemployment-insurance-claims-data-shed.html (Accessed: 24 August 2020).

Elgebal, D. (2020). Abu Ghosoun Village Savings and Loan Association Microcredit Program: A Progress Report for the period from March 2020 to July 2020. Marsa Alam, Red Sea, Egypt: Abu Ghosoun Community Development Association.. Available at: www.abughosoun.org (Accessed: 24 August 2020).

Falk, B. (2020). What will happen to the $7^{\text {th }}$ continent? BBC Travel. 12 October 2020. Available at: http://www.bbc.com/travel/ story/20201011-what-will-happen-to-the-7th-continent (Accessed: 17 October 2020).

Galvani, A., Lew, A.A. and Perez, M.S. (2020). COVID-19 is expanding global consciousness and the sustainability of travel and tourism. Tourism Geographies, 22 (3), 567-576.

Gateway and Natural Amenity Region Initiative (GNAR) (2020). Outdoor Recreation in Utah during the COVID-19 Pandemic.
Global Environment Facility (GEF) (2020). White paper on a GEF COVID-19 response strategy: The complexities and imperatives of Building Back Better, GEF/C59.Inf.14. 17 November 2020. 59 $9^{\text {th }}$ GEF Council Meeting, December 7-11. Virtual Meeting.

Hamdi, R. (2020). Coronavirus closures of Asian elephant camps offer respite to pursue reforms. Skift. 30 March 2020. Available at: https://skift.com/2020/03/30/coronavirus-closures -of-asian-elephant-camps-offer-respite-to-pursue-reforms/ (Accessed: 19 October 2020).

Hockings, M., Dudley, N., Elliott, W., Napolitano Ferreira, M., MacKinnon, K., Pasha, M.K.S., Phillips, A.et al. (2020). PARKS, 26 (1), 7-24.

Hvenegaard, G.T. and Shultis, J. (2016). The role of interpretation. In: P. Dearden, R. Rollins and M. Needham (eds.), Parks and Protected Areas in Canada: Planning and Management, pp. 141-169, $4^{\text {th }}$ Ed. Don Mills, ON,Canada: Oxford University Press.

Hvenegaard, G., Halpenny, E. and McCool, S. (2012). Protected area tourism and the Aichi targets. PARKS 18(2): 6-11.

Indonesian Geopark Commission (2019). Presidential Regulation Number 9 of 2019 concerning Development of Earth Parks (Geoparks).

Interagency Visitor Use Management Framework (2020). Available at: https://visitorusemanagement.nps.gov/VUM/Framework (Accessed: 15 November, 2020).

IUCN (2020). Conserving Nature in a time of crisis: Protected Areas and COVID-19. Available at: https://www.iucn.org/ news/world-commission-protected-areas/202005/conservingnature-a-time-crisis-protected-areas-and-covid-19. (Accessed: 3 September 2020).

James, H. (2020). Mara land owners weight options as Covid-19 bites. PDOnline, 11 June 2020. Available at: https:// www.pd.co.ke/business/economy-and-policy/mara-landowners-weigh-options-as-covid-19-bites-40160/? fbclid=IwAR1eqBQ09x4XRZLCiMaAWSLdH2I1CiciztwwX7T5 3I2a3O0Hd49C2G0-xwA. (Accessed: 7 October 2020).

Johnson, K. (2020). Tourism helps wildlife conservation - but we need to be thinking much bigger. Independent. 27 September 2020. Available at: https://www.independent.co.uk/voices/ coronavirus-environment-wildlife-tourism-africa-conservationillegal-trade-b624014.html (Accessed: 5 October 2020).

Kinsman, J. (2020). What kind of holidays will we take when we can travel again? Conde Nast Traveller. Available at: 2020 from https://www.cntraveller.com/article/future-travel. (Accessed: 5 October 2020).

Kingsford, R.T. and Biggs, H.C. (2012). Strategic adaptive management guidelines for effective conservation of freshwater ecosystems in and around protected areas of the world. IUCN WCPA Freshwater Taskforce. doi: 10.1016/ j.bicon.2010.09.022.

Kretchmer, H. (2020). These locked-down cities are being reclaimed by animals. World Economic Forum. 17 April 2020. Available at: https://www.weforum.org/agenda/2020/04/covid19-cities-lockdown-animals-goats-boar-monkeys-zoo/ (Accessed: 1 October 2020).

Leung, Y.-F., Spenceley, A., Hvenegaard, G.T. and Buckley, R. (eds.) (2018). Tourism and Visitor Management in Protected Areas: Guidelines for Sustainability (Best Practice Protected Area Guidelines Series No. 27). Gland, Switzerland: IUCN. 
Lindsey, P., Allan, J., Brehony, P., Dickman, A., Robson, A., Begg, C., Bhammar, H., et al. (2020). Conserving Africa's wildlife and wildlands through the COVID-19 crisis and beyond. Nature Ecology and Evolution https:// doi.org/10.1038/s41559-020-1275-6

Mitchell, J. and Ashley, C. (2010). Tourism and poverty reduction: Pathways to prosperity. London: Earthscan.

Naidoo, R., Gerkey, D., Hole, D., Pfaff, A., Ellis, A.M., Golden, C.D., Herrera, D., Johnson, K., Mulligan, M.I., Ricketts, T.H. and Fisher, B. (2019). Evaluating the impacts of protected areas on human well-being across the developing world. Science Advances, 5 (4), DOI: 10.1126/sciadv.aav3006

Naidoo, R., Weaver, C.L., Diggle, R.W. and Matongo, G. (2015). Complementary benefits of tourism and hunting to communal conservancies in Namibia. Conservation Biology, 30 (3), DOI: $10.1111 /$ cobi. 12643

Namibia Tourism Board (undated). Over $1.6 \mathrm{~m}$ tourists visited in 2019. Available at: http://www.namibiatourism.com.na/ industrynews/over-1-6m-tourists-visited-in-2019 Accessed: 31 August 2020.

National Park Service (2020a). National Park Service Visitor Spending Report 2020. Available at: https://www.nps.gov/ subjects/socialscience/vse.htm. (Accessed 18 August 2020).

National Park Service (2020b). COVID-19 safety and social distancing graphics. Available at: https://www.nps.gov/media/ photo/gallery.htm?pg=4913675\&id=CF41B3F2-A93D-4F38A482-CD02DD7488BD (Accessed: 3 September 2020).

Nationalpark Schwarzwald (2020). Besuchsaufkommen und Corona, 5 August 2020. Accessed on 31 August 2020 at https://www.nationalpark-schwarzwald.de/fileadmin/ Mediendatenbank_Nationalpark/04_Forschen/ Sozialwissenschaftlich/20200805_Besuchsaufkommen_und_ Corona_Rueede_Versand.pdf

Newsome, D. (2020). The collapse of tourism and its impact on wildlife tourism destinations. Journal of Tourism Futures https://doi.org/10.1108/JTF-04-2020-0053

Nunes, A. (2020). 'How Covid-19 will change air travel as we know it', BBC. Available at: https://www.bbc.com/future/ article/20200709-how-covid-19-will-change-air-travel-as-weknow-it (Accessed on 15 September 2020).

O'Brien, M. (2020). These 5 eco-friendly resorts around the world have survived the pandemic without guests by focussing on sustainability, caring for their orchards and farms, and delivering fresh food to locals. Business Insider Australia. 19 July 2020. Available at: https://www.businessinsider.com.au/ how-eco-friendly-resorts-around-world-survived-pandemicwithout-guests-2020-7? r=US\&IR=T (Accessed: 5 October 2020).

Peeters, P., Gössling, S., Klijs, J., Milano, C., Novelli, M., Dijkmans, C., Eijgelaar, E., Hartman, S., Heslinga, J., Isaac, R., Mitas, O., Moretti, S., Nawijn, J., Papp, B. and Postma, A. (2018). Research for TRAN Committee - Overtourism: impact and possible policy responses. Brussels: European Parliament, Policy Department for Structural and Cohesion Policies. [is:

Riley, E. (2020). What the future of adventure travel looks like. Outside. 21 May 2020. Available at: https:// www.outsideonline.com/2413863/future-adventure-travel-after -coronavirus-pandemic (Accessed: 5 October 2020).
Sarhan, M. (2016). Public-Private Partnership for Ecotourism Development in Wadi el Gemal National Park in Egypt, CEESP Members Newsletter 1619 - Aug 2016, IUCN.

Sarhan, M. (2017). A Public-Private Partnership Model for Ecotourism Development in Wadi el Gemal National Park. Sustainable Tourism in Small Island Developing States, from 22- 24th Nov 2017, Mahe, Seychelles

Sarhan, M. (2018). From the resort to ecotourism and agritourism: the challenge in Wadi el Gemal National Park, Egypt. Marsa Alam, Egypt. 1st World Congress on Agritourism Bolzano/ Bozen (Italy) 07- 09/11/2018

Shoji, K. (2020). Can micro-tourism save Japan's ailing travel industry. The Japan Times. 12 September 2020. Available at: https://www.japantimes.co.jp/news/2020/09/12/national/media -national/micro-tourism-travel-industry-coronavirus/ (Accessed: 5 October 2020).

Skinner, T. (2020). Virtual worlds: Can we travel without travelling? BBC. 31 March 2020. Available at: http://www.bbc.com/travel/ story/20200330-covid-19-virtual-travel-during-coronavirus (Accessed: 26 November 2020).

Snyman, S. and Spenceley, A. (2019). Private sector tourism in conservation areas in Africa. CABI.

Soliman, M. (2020). Wadi El Gemal Honey Project: A Progress Report for the period from March 2020 to July 2020. Marsa Alam, Red Sea, Egypt: Abu Ghosoun Community Development Association.

South African National Parks (SANParks) (2020). COVID-19 Safety message. Available at: https://www.sanparks.org/ about/covid-19.php (Accessed: 15 September 2020).

Souza, T.V.S.B., Chidakel, A., Child, B., Chang, W. and Gorsevski, V. (2020). Economic Effects Assessment Approaches: Tourism Economic Model for Protected Areas (TEMPA) for Developing Countries. In: A. Spenceley, (ed.) Handbook for sustainable tourism practitioners: The essential toolbox: Edward Elgar Publishing (in press).

Spenceley, A. (2020a). COVID-19 and protected area tourism: A spotlight on impacts and options in Africa, Report to the EU, Eurata Consortium.

Spenceley, A. (2020b). Tourism and visitation in protected areas amid COVID-19: Guidance for protected area authorities and managers, Report to the EU, Eurata Consortium.

Spenceley, A. (2020c). Setting the scene: Impacts of the pandemic on the tourism sector and building back greener. Online side event of the $26^{\text {th }}$ Meeting of the UNECE Committee on Environmental Policy. 9 November 2020. Available at: https:// www.oneplanetnetwork.org/transforming-tourism-resilient-and -sustainable-post-covid-world-event-summary (Accessed: 22 November 2020).

Spenceley, A. (2020d). Building nature-based tourism back from COVID-19: Recovery, resilience and sustainability. Report to the Luc Hoffmann Institute. 12 November 2020.

Spenceley, A. and Rylance, A. (2019). The contribution of tourism to achieving the sustainable development goals. In: S. McCool and K. Bosak (eds.) A research agenda for sustainable tourism, pp. 107-125. Edward Elgar Publishing.

Tripadvisor (2020). Beyond COVID-19: The road to recovery for the travel industry. Available at: https://www.tripadvisor.com/ Covid19WhitepaperMay2020 (Accessed on 10 September 2020). 
UN News (2020). 'Devastated by pandemic, tourism sector must be rebuilt in a safe, equitable and climate friendly way - UN chief'. UN News 25 August 2020. Available at: https:// news.un.org/en/story/2020/08/1070902 (Accessed: 5 October 2020).

UN World Tourism Organization (UNWTO) (2019). 'Overtourism'? Understanding and managing urban tourism growth beyond perceptions. (Volumes 1 and 2).

UN World Tourism Organization (UNWTO) (2020a). Impact Assessment of the COVID-19 Outbreak on International Tourism. UNWTO Reports. Available at: https:// www.unwto.org/impact-assessment-of-the-covid-19-outbreakon-international-tourism (October 2020).

UNWTO (2020b). . UNWTO Reports. Available at: https:// www.unwto.org/news/covid-19-response-travel- restrictions? fbclid=IwAR3YJtncEvUpNjAAAQqYlaYwcMnQucqCsnBdVm9 19ILa968vWiv0UAlmVbk (Accessed: 21 April 2020).

UNWTO (2020c). Understanding domestic tourism and seizing its opportunities, UNWTO Briefing Note - Tourism and COVID19, issue 3. Available at: https://www.e-unwto.org/doi/ epdf/10.18111/9789284422111 (Accessed: 15 September 2020).
UNWTO (2020d). One Planet vision for a responsible recovery of the tourism sector. Available at: https://www.unwto.org/covid19-oneplanet-responsible-recovery-initiatives (Accessed: 10 October 2020).

World Bank (2020). Tools and Resources for Nature-Based Tourism. Washington, DC: World Bank. (c) World Bank. Available at: https://openknowledge.worldbank.org/ handle/10986/34433 License: CC BY 3.0 IGO

World Travel and Tourism Council (WTTC) (2019). Economic impact of global wildlife tourism._Available at:_https:// www.atta.travel/news/2019/08/the-economic-impact-of-globalwildlife-tourism-wttc/ (Accessed: 10 October 2020).

WTTC (2020a). '174 m travel and tourism jobs could be lost due to COVID-19 and travel restrictions, says WTTC'. 29 October 2020. Available at: https://wttc.org/News-Article/174m-Travel\&-Tourism-jobs-could-be-lost-due-to-COVID-19-and-travelrestrictions (Accessed: 27 November 2020).

WTTC (2020b). Recovery Dashboard. Available at: https://wttc.org/ Initiatives/Recovery-Dashboard (Accessed: 3 September 2020).

WWF-Namibia (2020). Mitigating the impacts of the COVID-19 virus to Namibia's communal conservancies. Unpublished report.

\footnotetext{
Author affiliations (continued)

${ }^{9}$ Environmental Studies and Outdoor Education, University of Alberta, Camrose, Alberta.

${ }^{10}$ University of Alberta's Augustana Campus, Camrose, Alberta.

${ }^{11}$ The Long Run, United Kingdom

${ }^{12}$ Department of Parks, Recreation and Tourism Management, North Carolina State University, USA

${ }^{13}$ University of Split, Faculty of Economics, Business and Tourism, Croatia.

${ }^{14}$ WWF-US, Washington, DC, USA; Institute for Resources, Environment and Sustainability, University of British Columbia, Vancouver, BC, Canada

${ }^{15}$ Nationalparkzentrum am Ruhestein, Germany

${ }^{16}$ WWF-US, Washington, DC, USA

${ }^{17}$ School of Hospitality, Tourism and Events, Auckland University of Technology, New Zealand

${ }^{18}$ Public Use Mananagement, Galapagos National Park Directorate, Ecuador

${ }^{19} \mathrm{Chico}$ Mendes Institute for Biodiversity Conservation (ICMBio), Brazil

${ }^{20}$ The Long Run, Kenya
} 


\section{RESUMEN}

La pandemia del COVID-19 ha tenido un impacto global en el sector del turismo. Al reducirse drásticamente el número de turistas, podrían perderse millones de puestos de trabajo, y los avances logrados en materia de igualdad y crecimiento económico sostenible podrían retroceder. Los informes generalizados de cambios drásticos en la visita a áreas protegidas y conservadas tienen consecuencias negativas para las finanzas de la conservación, las empresas turísticas y los medios de vida de las personas que suministran mano de obra, bienes y servicios a los turistas y a las empresas turísticas. El presente artículo tiene por objeto compartir experiencias de todo el mundo sobre los efectos de la pandemia del COVID-19 en el turismo de las áreas protegidas; y examina la forma de fomentar la capacidad de resiliencia del turismo de las áreas protegidas como instrumento regenerativo de conservación.

\section{RÉSUMÉ}

La pandémie de COVID-19 a eu un impact certain au niveau mondial sur le secteur du tourisme. Suite à la réduction spectaculaire du nombre de touristes, des millions d'emplois pourraient être perdus et les progrès réalisés en matière d'égalité et de croissance économique durable pourraient s'en trouver annulés. De nombreux rapports sur les chutes drastiques dans la fréquentation des aires protégées et conservées font état de ces conséquences négatives sur les finances de la conservation, les entreprises touristiques et les moyens de subsistance des personnes qui fournissent de la main d'oeuvre, des biens et des services aux touristes et aux entreprises touristiques. Le présent document vise à partager les expériences provenant du monde entier relatives aux conséquences de la pandémie de COVID-19 sur le tourisme des aires protégées, et examine comment renforcer la résilience du tourisme des aires protégées en tant qu'outil de conservation régénérative. 